\title{
Indications of the extraction of symptomatic impacted third molars. A systematic review
}

\author{
María Peñarrocha-Diago ${ }^{1}$, Octavi Camps-Font ${ }^{2}$, Alba Sánchez-Torres ${ }^{2}$, Rui Figueiredo ${ }^{3}$, María-Angeles \\ Sánchez-Garcés ${ }^{4}$, Cosme Gay-Escoda ${ }^{5}$
}

\begin{abstract}
${ }^{1}$ DDS, MS, PhD. Assistant Professor of Oral Surgery. University of Valencia Medical and Dental School. Valencia, Spain. Researcher of the "Dental and Maxillofacial Diseases and Therapeutics" group of the Bellvitge Biomedical Research Institute (IDIBELL) ${ }^{2}$ DDS, MS. Associate Professor of Oral Surgery. University of Barcelona Dental School. Barcelona, Spain. Researcher of the "Dental and Maxillofacial Diseases and Therapeutics" group of the Bellvitge Biomedical Research Institute (IDIBELL)

${ }^{3} \mathrm{DDS}, \mathrm{MS}, \mathrm{PhD}$. Associate Professor of Oral Surgery. Coordinator of the Master of Oral Surgery and Buccofacial Implantology. University of Barcelona. Barcelona, Spain. Researcher of the "Dental and Maxillofacial Diseases and Therapeutics" group of the Bellvitge Biomedical Research Institute (IDIBELL)

${ }^{4}$ MD, DDS, MS, PhD, EBOS. Associate Professor of Oral Surgery. University of Barcelona Dental School. Barcelona, Spain. Subdirector of the Master of Oral Surgery and Buccofacial Implantology of the EFHRE International University / FUCSO. Researcher of the "Dental and Maxillofacial Diseases and Therapeutics" group of the Bellvitge Biomedical Research Institute (IDIBELL)

${ }^{5} \mathrm{MD}$, DDS, MS, PhD, EBOS, OMFS. Chairman of Oral and Maxillofacial Surgery. University of Barcelona Dental School. Barcelona, Spain. Director of the Master of Oral Surgery and Buccofacial Implantology of the EFHRE International University / FUCSO. Coordinator / Researcher of the "Dental and Maxillofacial Diseases and Therapeutics" group of the Bellvitge Biomedical Research Institute (IDIBELL)
\end{abstract}

Correspondence:

Departamento de Estomatología

Universitat de València

C/ Gascó Oliag 1

46010 - Valencia, Spain

maria.penarrocha@uv.es

Peñarrocha-Diago MA, Camps-Font O, Sánchez-Torres A, Figueiredo R, Sánchez-Garcés MA, Gay-Escoda C. Indications of the extraction of symptomatic impacted third molars. A systematic review. J Clin Exp Dent. 2021;13(3):e278-86.

Received: $05 / 02 / 2020$

Accepted: 21/05/2020

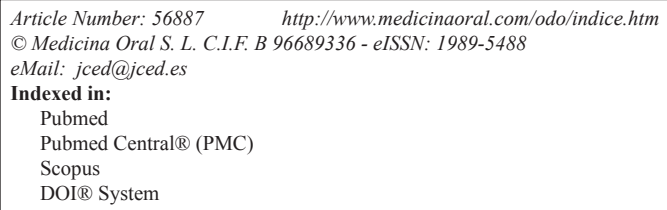

\begin{abstract}
Background: A literature review was made to determine when third molar (3M) extraction is recommended in symptomatic patients and when it is not recommended.

Material and Methods: A Medline (PubMed) and EMBASE search was made for articles related to indications for the extraction of 3Ms, published in the last 10 years and up until September 2018.

Results: The electronic search yielded 175 articles. After eliminating duplicates, a total of 173 articles were subjected to review of the title and abstract. Only 19 studies were finally included in the systematic review. There was a well documented increase in morbidity associated to impacted 3Ms (non-restorable caries, fracture, infection, periodontal disease, repeated pericoronitis, cysts and tumors), and in the presence of disease, extraction was considered to be indicated. The extraction of $3 \mathrm{Ms}$ with signs and/or symptoms of periodontal disease improved periodontal health at the distal surface of the second molar. Postoperative quality of life of patients with symptomatic 3Ms and with disease improved after surgical extraction.

Conclusions: Extraction is indicated in the presence of disease associated to an impacted 3M, whether symptomatic or not. In contrast, extraction is not indicated in the absence of infection or other associated disease conditions.
\end{abstract}

Key words: Third molar, periodontal disease, periodontitis, pericoronitis, dental caries, occlusal caries, mandibular cysts, osteomyelitis, odontogenic tumor. 


\section{Introduction}

One of the most important scenarios in dental practice, and particularly in oral surgery, is the presence of diseases and/or complications associated to wisdom teeth or third molars $(3 \mathrm{Ms})$, derived from eruption disorders that adversely affect the periodontal health of the neighboring teeth $(1,2)$. Indeed, third molar extraction is the most frequent type of surgery performed by dental surgeons (3). Extraction and the indication of extraction must be based on scientific evidence allowing us to make solid decisions for the benefit of our patients (4). However, there is controversy regarding the prophylactic removal of asymptomatic impacted $3 \mathrm{Ms}$ without associated disease $(5,6)$. In this context, it must be taken into account that "asymptomatic" does not discard the possible existence of disease $(3,7)$.

An increasingly relevant concept in prophylaxis is being able to distinguish between patients with no molar symptoms but with associated disease and those with molar symptoms but no associated disease. In the presence of signs or symptoms produced by a $3 \mathrm{M}$ (pain, infection, local and/or regional swelling, etc.), patients tend to visit in search of the best possible treatment, which in most cases will consist of surgical or nonsurgical extraction, conditioned to cost-benefit criteria.

However, in many cases there are no such signs or symptoms, despite the presence of disease associated to the position of the third molar (periodontal pockets at the distal surface of the adjacent second molar, impacted molar follicle enlargement, cysts, root reabsorption, etc.) $(8-11)$.

Thus, prophylactic extraction (i.e., removal of the tooth in the absence of symptoms and without disease) must be decided based on a number of prior considerations, of which two are particularly important: (a) What are the chances that the impacted $3 \mathrm{M}$ will cause disease at some point in the life of the patient? (b) What morbidity can be expected from removing the molar in a young patient under 25 years of age? This latter issue is clearly pertinent, considering the increasing life expectancy of the population (6).

The present literature review was made to determine those cases in which $3 \mathrm{M}$ extraction is recommended in symptomatic patients and in which cases it is not recommended.

In addition, we aimed to establish the indication for the removal of asymptomatic impacted $3 \mathrm{Ms}$ with or without associated disease, and to determine which patients with associated disease are likely to have a better outcome in terms of the appearance of complications.

\section{Material and Methods}

The literature review was carried out based on the PRISMA criteria (12), and our search strategy was guided by the following modified PICO (Population, Intervention,
Comparison, Outcome) question (13): What are the indications for extracting third molars that are impacted, produce symptoms or present associated disease?

-Electronic search

A Medline (PubMed) and EMBASE search was made for articles related to indications for the extraction of $3 \mathrm{Ms}$, published in the last 10 years and up until September 2018. We used MeSH (Medical Subject Headings) terms as well as non-MeSH or Free-Text terms, combined with the boolean operators OR / AND as follows: -MEDLINE (PUBMED):

(((("Molar, Third”[Mesh] OR wisdom teeth OR wisdom tooth OR third molar OR third molars) AND ("Tooth Extraction"[Mesh] OR removal OR nonextraction OR management))) AND ((symptomatic OR second molar OR periodontal health OR periodontal status OR probing depth OR periodontal pocket OR "Pericoronitis"[Mesh] OR pericoronitis OR impacted OR included OR occlusal caries OR cervical caries OR odontogenic cyst OR “Jaw Cysts”[Mesh]) OR “Osteomyelitis”[Mesh])) AND (indication OR indications)

-EMBASE:

((('molar tooth'/exp OR 'molar tooth' OR wisdom) AND ('tooth'/exp OR tooth) OR wisdom) AND ('teeth'/exp OR teeth)) AND ((('tooth extraction' OR tooth) AND removal OR tooth) AND (non AND extraction OR management)) AND $(((()((($ (impacted AND third AND molar OR symptomatic) AND third AND molar OR second) AND molar OR 'periodontal disease' OR periodontal) AND health OR periodontal) AND status OR 'probing depth' OR 'periodontal pocket' OR periodontal) AND pocket OR 'gingiva disease' OR pericoronitis OR occlusal) AND caries OR cervical) AND caries OR 'odontogenic tumor' OR 'jaw cyst' OR jaw) AND cyst OR 'osteomyelitis')

-Inclusion criteria:

- Randomized clinical trials (RCTs) or non-randomized trials, observational cohort studies, case-control studies and case series (at least 10 cases) involving a cross-sectional design.

- Evaluation of the prophylactic extraction of impacted or non-impacted symptomatic third molars with associated disease.

-Exclusion criteria:

- Publications in languages other than English, French or Spanish.

- Preclinical / in vitro studies, finite element studies or necropsy studies.

\section{Results}

The Medline (PubMed) and EMBASE search yielded 175 articles. After eliminating duplicates, a total of 173 articles were subjected to review of the title and abstract. Only 19 studies were finally included in the systematic review (Fig. 1). 


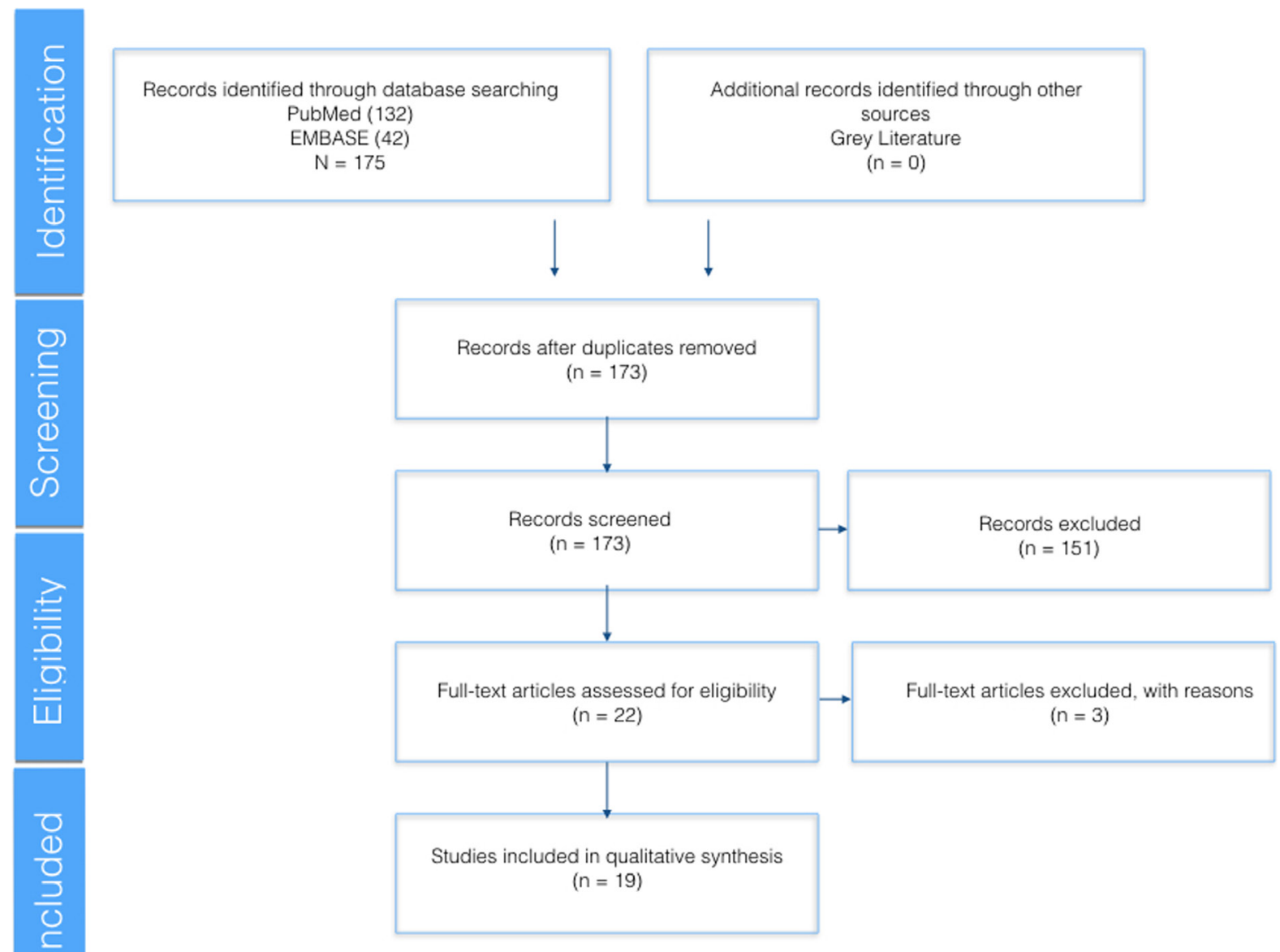

Fig. 1: Flow chart of the selection of articles according to the PRISMA criteria (12).

The main indication for the extraction of the $3 \mathrm{Ms}$ was the presence of associated disease (14-17). The existing evidence for extracting or not extracting asymptomatic $3 \mathrm{Ms}$ without disease was found to be inconclusive (6); monitoring was thus advised (17), with due assessment of the risk-benefit ratio $(18,19)$.

The scientific evidence therefore suggests that erupted and impacted $3 \mathrm{Ms}$ should be removed in the presence of painful symptoms associated to infection, dental caries or altered periodontal health of the adjacent teeth. Likewise, removal is considered to be indicated when the molar may pose problems for planned prosthodontic, orthodontic or surgical treatments.

In view of the well documented increase in morbidity associated to impacted 3Ms (non-restorable caries, fracture, infection, periodontal disease, repeated pericoronitis, cysts and tumors), extraction is considered to be indicated if associated disease is present. In contrast, prophylactic removal is not indicated in the absence of infection or other associated diseases.

-Extraction of third molars with pericoronitis

Pericoronitis is one of the associated disease conditions in which $3 \mathrm{M}$ extraction is considered to be indicated. It is characterized by inflammation of the mucosa surrounding the crown of the molar, with pain and sometimes erythema, edema and localized suppuration. Patients with pericoronitis can also present regional adenopathies, fever, trismus and swallowing pain, which is common in the case of inferior $3 \mathrm{Ms}$ and constitutes an indication for removal of the tooth.

Nevertheless, there is some controversy regarding the extraction of $3 \mathrm{Ms}$ with pericoronitis. Some authors advise basing the decision on the evidence afforded by the clinical guides, with the recommendation to limit intervention to the monitoring of those patients with one or two episodes of mild pericoronitis, associated to periodontal therapy and the maintenance of low bacterial plaque levels $(20,21)$.

A study published by Tang et al. (22), involving 113 patients with symptoms of pericoronitis, considered that patient opinion should be taken into account in deciding treatment, since 79 patients chose extraction mainly because of altered oral function, with a minimum impact upon quality of life (odds ratio [OR] 3.22; 95\% confidence interval [95\%CI]: 1.08-9.58).

Apart from $3 \mathrm{Ms}$ in a favorable position that have cau- 
sed one or two episodes of mild transient pericoronitis which can be controlled by periodontal treatment with the maintenance of a low bacterial plaque levels, the rest of $3 \mathrm{Ms}$ causing more severe and repeated infection should be removed (17).

Although the surgical management of pericoronitis is subject to controversy, this disorder is currently the most frequent reason for removing impacted $3 \mathrm{Ms}$, particularly because patients with active pericoronal tissue infection stand to benefit from improved quality of life over the long term - this being a factor to be taken into account when considering possible extraction (21).

-Periodontal condition of the second molar

In some cases, as in the study published by Blakey et al. (15), the absence of symptoms of impacted 3Ms does not imply the absence of disease. In a sample of 329 patients, $25 \%$ of the second molars (2Ms) and $35 \%$ of the $3 \mathrm{Ms}$ presented a probing depth (PD) of $>5 \mathrm{~mm}$. In this regard, the observation of signs of periodontal disease in asymptomatic 2Ms and 3Ms constitutes an unexpected finding (15).

These observations suggest that patients who wish to preserve their molars should undergo periodic clinical and radiographic evaluations in order to detect disease before it begins to cause symptoms $(6,19)$.

On the other hand, the factors giving rise to postoperative complications comprise patient-related characteristics, anatomical factors, surgical factors and the type of associated disease $(16,17)$. According to Chuang et al. (16), the degree of impaction, pre-existing infection and associated disease of $3 \mathrm{Ms}$ are associated to an increased risk of postoperative inflammatory complications. Among individuals with preoperative infection, 25\% experienced postoperative inflammatory problems (OR 1.25 ; 95\%CI: 1.01-1.6), while those with associated disease were three times more likely to suffer such postoperative complications (OR 3.0; 95\%CI 2.2-4.3) (16).

Dicus-Brookes et al. (3) performed periodontal probing of $2 \mathrm{Ms}$ before and after the extraction of $3 \mathrm{Ms}$, with the observation of significant differences: while $88 \%$ of the patients presented a PD of about $4 \mathrm{~mm}$ before extraction, this percentage decreased to only $46 \%$ after the operation $(p<0.001)$. Furthermore, $61 \%$ presented at least one site with PD $>4 \mathrm{~mm}$ in other teeth located anterior to $2 \mathrm{M}$ before the operation, versus only $29 \%$ after surgery $(p<0.001)$. The removal of $3 \mathrm{Ms}$ improved the periodontal condition of the $2 \mathrm{Ms}$ and of the teeth in a more anterior position, thanks to the decreased presence of oral pathogens (3).

Another similar study documented patients with $\mathrm{PD} \geq 5$ $\mathrm{mm}$ around $3 \mathrm{M}$, with an attachment loss of $2 \mathrm{~mm}$, while other molars presented $\mathrm{PD}<4 \mathrm{~mm}$ with an attachment loss of $1 \mathrm{~mm}$. The presence of 3Ms in young adults was associated with periodontal disease of other teeth. Extraction of the mandibular 3Ms improved the periodontal condition at the distal surface of $2 \mathrm{M}$ (19).
The above observations are consistent with those previously published by Dodson and Richardson in 2007 (23). These authors concluded that following $3 \mathrm{M}$ extraction, the periodontal health at the distal surface of $2 \mathrm{M}$ should remain constant or improve if the patient previously presented periodontal pockets or attachment loss. However, those individuals without associated disease of their 3Ms (i.e., with a healthy periodontal condition) were seen to be at greater risk of developing periodontal pockets distal to $2 \mathrm{M}$ after removal of $3 \mathrm{M}$ (23). The prescription of chlorhexidine following the extraction of $3 \mathrm{Ms}$ in eruption processes with periodontal disease or other preoperative disorders was associated with a shorter time to recovery (less than two days on average) (14).

-Periodontal disease of the third molars

In the presence of periodontal disease of $3 \mathrm{M}$, the clinician can either extract the molar or provide regular periodontal maintenance. It is not advisable to remove asymptomatic $3 \mathrm{Ms}$ without disease. However, extraction is indicated when periodontal pockets are detected, particularly if the patient exhibits deficient oral hygiene or periodontal maintenance is not feasible. All these factors should be evaluated in order to make an individualized management decision (17).

The extraction of $3 \mathrm{M}$ with signs and/or symptoms of periodontal disease improves periodontal health at the distal surface of $2 \mathrm{M}$. However, in subjects with healthy periodontal tissue surrounding $2 \mathrm{M}$, the extraction of $3 \mathrm{M}$ must be evaluated carefully, since probing depth and the clinical attachment level tend to worsen as a result (29). -Postoperative morbidity following the extraction of symptomatic third molars

Bradshaw et al. (24) evaluated the effect of the extraction of $3 \mathrm{M}$ upon the quality of life $(\mathrm{QoL})$ of individuals with symptoms of pericoronitis. They found the proportion of patients with severe pain to decrease from $32 \%$ before extraction to $3 \%$ after removal of the tooth. On the other hand, the proportion of patients with no pain or only very mild pain was seen to increase from $15 \%$ before extraction to $96 \%$ in the first days after removal of the tooth. The authors concluded that the extraction of $3 \mathrm{Ms}$ had a positive impact upon the quality of life of the patients with mild symptoms of pericoronitis.

The extraction of $3 \mathrm{Ms}$ with disease before surgery induces a delay in recovery after extraction, since postoperative morbidity is incremented as a result $(12,13)$. According to Philips et al. (13), clinical recovery was delayed in those patients who already presented symptoms before removal and who needed to be seen at least once after extraction for the treatment of postoperative complications. This delay in recovery could be related to microbial colonization of the surgical wound (13).

Patient age and gender, and 3M position below the occlusal plane were significantly associated to prolonged 
recovery (13). Age and gender, and surgeon perceived difficulty of extraction were identified as statistically significant predictors of delayed healing. Women and patients who had symptomatic $3 \mathrm{Ms}$ before surgical extraction showed slower clinical recovery (13).

Colorado-Bonnin et al. (25) evaluated the time needed to recover the quality of life of patients subjected to the surgical extraction of the 3Ms. They found men to report less pain than women, though the gender difference failed to reach statistical significance. The surgical removal of lower $3 \mathrm{Ms}$ was concluded to have a significant impact upon of the patient during the first three postoperative days. The quality of life of patients with symptomatic $3 \mathrm{Ms}$ and disease improved after surgical extraction. In the opinion of Krishnan et al. (26), the removal of symptomatic lower 3Ms appears to be the most logical treatment option.

Patients with impacted lower $3 \mathrm{Ms}$ are more susceptible to fracture of the mandibular angle as a complication of extraction (27). Older age is associated to an increased risk of mandibular fracture and of other complications secondary to systemic causes that may lead to the contraindication of extraction (28).

Postoperative morbidity associated to prolonged recovery was prospectively evaluated by Phillips et al. (30), with the identification of significant predictors such as age, gender, previous symptoms, and surgeon perceived difficulty of extraction (30). In addition, an impacted molar position below the occlusal plane was significantly associated to prolonged recovery, (Table 1, 1 cont., 1 cont.-1).

\section{Discussion}

The present literature review was made to determine when third molar $(3 \mathrm{M})$ extraction is recommended in symptomatic patients and when it is not recommended, as well as to establish the indications for the removal of impacted asymptomatic 3Ms with or without disease, and determine which cases of $3 \mathrm{Ms}$ with associated disease exhibit a better clinical course in terms of postoperative complications.

A literature search was made to identify those studies most relevant to the objectives of our study. The collected evidence suggests that the main indication of extraction is the presence of associated disease (14-17), though the data are not conclusive in the case of asymptomatic impacted 3Ms without associated disease (6). In such situations monitoring is advised (17), with due assessment of the risk-benefit ratio of surgical removal $(18,19)$.

The extraction of $3 \mathrm{Ms}$ with pericoronitis remains subject to controversy, since the decision must be based not only on the existing evidence and surgeon experience but also on the preferences of the patient. In the case of individuals with one or two episodes of mild pericoronitis, the recommendation is to not remove the molar and to monitor the patient, ensuring good bacterial plaque control $(20,21)$. Impaired oral functions and altered quality of life may be reasons for indicating extraction (22). It should be noted that the absence of associated symptoms in patients with impacted $3 \mathrm{Ms}$ does not necessarily imply the absence of disease (15). In this regard, patients who are reluctant to accept the removal of an asymptomatic molar should undergo periodic clinical and radiological controls $(6,19)$. Other local and demographic factors such as the level of impaction, pre-existing disease and the relationship of the molar with the occlusal plane also must be taken into account $(16,17)$. The periodontal health of the $2 \mathrm{M}$ adjacent to an impacted $3 \mathrm{M}$ may be altered, due to the presence of periodontal pockets (3). The evidence compiled by the present review is not intended to modify the treatment recommendations but to widen our perspective of the management of impacted $3 \mathrm{Ms}$ as one of the most frequent situations found in routine clinical practice. The main limitation of our study is that no recommendations were made based on the methodological quality of the studies. It was not our intention to establish such recommendations, since there were many confounding factors that precluded the drawing of firm conclusions, due to the heterogeneity of the studies included in the review.

In many cases no clear and firm evidence could be obtained; indeed, the collected data were largely imprecise - thus underscoring the need for further research in this field, on a more standardized basis and involving models of greater scientific quality.

Additional longitudinal studies are needed, exploring the evolution of periodontal disease in patients with mild pericoronitis subjected to conservative periodontal treatment without $3 \mathrm{M}$ extraction, compared with patients in which $3 \mathrm{M}$ is removed. This would help to improve our understanding of the general periodontal health impact of either $3 \mathrm{M}$ removal or more conservative management in the form of adequate patient monitoring. Lastly, studies are needed to analyze postoperative morbidity according to the different types of disease associated to $3 \mathrm{M}$ before surgical removal.

\section{Conclusions}

Since there is a well documented increase in morbidity associated to impacted $3 \mathrm{Ms}$ (non-restorable caries, fracture, infection, periodontal disease, repeated pericoronitis, cysts and tumors), extraction is considered indicated in the presence of disease of the impacted molar. However, in the absence of infection or other associated disease conditions, extraction is not indicated. The extraction of $3 \mathrm{Ms}$ with preoperative disease results in delayed recovery after removal, since postoperative morbidity is incremented as a result. 
Table 1: Descriptive summary of the studies included in the review.

\begin{tabular}{|c|c|c|c|c|}
\hline Author/year & Type of study & Objectives & Results & Conclusions \\
\hline $\begin{array}{l}\text { Blakey et al. } \\
2002(15)\end{array}$ & $\begin{array}{l}\text { Longitudinal } \\
\text { clinical trial }\end{array}$ & $\begin{array}{l}\text { Report the prevalence of } \mathrm{PD} \text { as a } \\
\text { clinical measure of the extent of } \\
\text { periodontitis associated to } \\
\text { asymptomatic } 3 \mathrm{Ms} \text { in the initial } \\
\text { examination of a cohort of } \\
\text { patients enrolled in a longitudinal } \\
\text { clinical trial. }\end{array}$ & $\begin{array}{c}\mathrm{N}: 329 \\
\text { * In patients }>25 \text { years, PD was }>5 \mathrm{~mm} \text { distal } \\
\text { to } 2 \mathrm{Ms} \text { or around } 3 \mathrm{Ms} \text { in comparison with } \\
\text { patients }<25 \text { years }(33 \% \text { versus } 17 \% \\
\mathrm{p}=0.002) \\
\text { * The distal zones of mandibular } 2 \mathrm{Ms} \text { were } \\
\text { more often affected than those of upper } 2 \mathrm{Ms} \\
(25 \% \text { versus } 5 \% ; \mathrm{p}=0.0001) .\end{array}$ & $\begin{array}{l}* 25 \% \text { of the patients with asymptomatic } \\
\text { impacted } 3 \text { Ms present considerable periodontal } \\
\text { disease in the region of the molar. The national } \\
\text { epidemiological surveys indicate a much lower } \\
\text { incidence of periodontitis in the population } \\
\text { under } 35 \text { years of age. }\end{array}$ \\
\hline $\begin{array}{l}\text { Phillips et al. } \\
2003(30)\end{array}$ & $\begin{array}{l}\text { Prospective } \\
\text { clinical trial }\end{array}$ & $\begin{array}{l}\text { Identify the demographic, oral } \\
\text { health and surgical risk factors } \\
\text { associated to prolonged recovery } \\
\text { after } 3 \mathrm{M} \text { extraction using the } \\
\text { HRQoL and clinical outcomes. }\end{array}$ & $\begin{array}{l}\text { N: } 547 \\
\text { * Age, gender and the position of the occlusal } \\
\text { plane of 3Ms was significantly associated with } \\
\text { prolonged recovery. } \\
\text { * Lifestyle recovery was prolonged only if the } \\
\text { lower 3Ms were below the occlusal plane } \\
\text { before surgery. } \\
\text { Statistically significant predictors of late } \\
\text { clinical recovery: age, gender, previous } \\
\text { symptoms and surgeon perceived difficulty. }\end{array}$ & $\begin{array}{l}\text { * Demographic and oral health conditions } \\
\text { considered by the surgeon before extraction, } \\
\text { and the characteristics of surgery itself, } \\
\text { increase the risk of prolonged recovery of } \\
\text { HRQoL. }\end{array}$ \\
\hline \multirow[t]{2}{*}{$\begin{array}{l}\text { Gutiérrez- } \\
\text { Pérez } 2004 \\
(21)\end{array}$} & \multirow[t]{2}{*}{$\begin{array}{l}\text { Literature } \\
\text { review }\end{array}$} & \multirow[t]{2}{*}{$\begin{array}{c}\text { Pericoronitis, its clinical, } \\
\text { histological and microbiological } \\
\text { characteristics, and management } \\
\text { approach. }\end{array}$} & $\begin{array}{c}* \text { Antimicrobial treatment is indicated as } \\
\text { preoperative prophylaxis in the presence of a } \\
\text { high risk of infection, and in acute phase } \\
\text { suppurative pericoronitis, where surgery is to } \\
\text { be postponed. } \\
\text { * Amoxicillin - clavulanic acid is the treatment } \\
\text { of choice. }\end{array}$ & $\begin{array}{l}\text { The management of pericoronitis can be } \\
\text { addressed from three perspectives: }\end{array}$ \\
\hline & & & $\begin{array}{l}* \text { The surgical treatment of pericoronitis } \\
\text { present in } 3 \mathrm{Ms} \text { is the most common indication } \\
\text { for the removal of impacted } 3 \mathrm{Ms} \text {, due to the } \\
\text { patient benefits afforded in terms of QoL. }\end{array}$ & $\begin{array}{l}\text { - Symptomatic measures } \\
\text { - Antimicrobial measures } \\
\text { - Surgical measures }\end{array}$ \\
\hline $\begin{array}{l}\text { Richardson et } \\
\text { al. } 2005 \text { (29) }\end{array}$ & $\begin{array}{l}\text { Literature } \\
\text { review }\end{array}$ & $\begin{array}{l}\text { What is the risk of periodontal } \\
\text { defects distal to lower } 2 \mathrm{M} \text { after } \\
3 \mathrm{M} \text { extraction? }\end{array}$ & $\begin{array}{c}\text { Changes in CAL or PD } 6 \text { months after 3M } \\
\text { extraction: } \\
\text { - Clinically insignificant in the distal portion of } \\
2 \mathrm{M} \text {. } \\
\text { * In patients with healthy periodontal } \\
\text { conditions before surgery, } 48 \% \text { showed } \\
\text { worsening of the periodontal measures after } \\
\text { extraction. }\end{array}$ & $\begin{array}{l}* \text { Generally, PD of } 2 \mathrm{M} \text { or CAL remain without } \\
\text { change or improve after } 3 \mathrm{M} \text { extraction. } \\
\text { * In patients with healthy periodontal tissue of } \\
2 \mathrm{M} \text { before extraction, the indication of } 3 \mathrm{M} \\
\text { removal must be made with caution, since } \\
\text { these subjects are at an increased risk of } \\
\text { worsened PD or CAL after extraction. }\end{array}$ \\
\hline \multirow{2}{*}{$\begin{array}{l}\text { Colorado- } \\
\text { Bonnin et al. } \\
2006(25)\end{array}$} & \multirow{2}{*}{$\begin{array}{l}\text { Survey-based } \\
\text { study }\end{array}$} & \multirow{2}{*}{$\begin{array}{l}\text { Evaluate QoL and degree of } \\
\text { satisfaction among adult } \\
\text { ambulatory patients after lower } \\
\text { 3M extraction. }\end{array}$} & \multirow[b]{2}{*}{$\begin{array}{c}\text { N: } 91 \text { Caucasian patients completed the } \\
\text { questionnaire. F: } 53 / \mathbf{M}: 38 \\
\text { Test group: } 45 \text { patients Control group: } 46 \\
\text { patients } \\
\text { Mean age: } 25.1 \text { years, SD } 7.6 \text { years } \\
\text { Most frequent position of 3Ms (according to } \\
\text { classifications of Winter and Pell \& Gregory): } \\
\text { mesioangular and IIB, respectively. }\end{array}$} & * Males reported less pain than females. \\
\hline & & & & $\begin{array}{c}\text { * Lower 3M surgery has a significant impact in } \\
\text { terms of QoL, particularly in the first } 3 \text { days } \\
\text { after extraction. }\end{array}$ \\
\hline \multirow[t]{4}{*}{$\begin{array}{l}\text { Adeyemo } \\
2006(27)\end{array}$} & \multirow[t]{4}{*}{$\begin{array}{l}\text { Literature } \\
\text { review }\end{array}$} & \multirow[t]{4}{*}{$\begin{array}{l}\text { Relationship between lower } \\
\text { impacted } 3 \mathrm{Ms} \text {, cysts, tumor } \\
\text { development and mandibular } \\
\text { fractures. }\end{array}$} & $\begin{array}{l}\text { *The proportion of impacted } 3 \mathrm{Ms} \text { that are } \\
\text { removed without clinically valid justification is } \\
18-50.7 \% \text {. }\end{array}$ & $\begin{array}{l}\text { * Patients with impacted lower 3Ms are more } \\
\text { susceptible to mandibular angle fracture. }\end{array}$ \\
\hline & & & $\begin{array}{c}\text { *The justifications for prophylactic surgery } \\
\text { include: }\end{array}$ & $\begin{array}{l}* \text { The presence of } 3 \mathrm{Ms} \text { helps prevent condylar } \\
\text { fractures, which are more serious, difficult to } \\
\text { treat and have a greater risk of complications. }\end{array}$ \\
\hline & & & $\begin{array}{l}\text { - Minimize risk of disease development (cysts } \\
\text { and tumors) }\end{array}$ & $\begin{array}{l}* \text { The prophylactic removal of impacted lower } \\
\text { 3Ms should be suspended in the absence of } \\
\text { specific complications. }\end{array}$ \\
\hline & & & $\begin{array}{l}\text { - Reduction of mandibular angle fracture risk } \\
\text { - Greater surgical difficulty with advancing age } \\
\text { - 3Ms play no defined role in mouth }\end{array}$ & $\begin{array}{c}* \text { The removal of impacted } 3 \mathrm{Ms} \text { should be } \\
\text { limited to those teeth with a well defined } \\
\text { diagnosis and clear surgical or pathological } \\
\text { indications. }\end{array}$ \\
\hline \multirow[t]{3}{*}{$\begin{array}{l}\text { Marciani et } \\
\text { al. } 2007(28)\end{array}$} & \multirow[t]{3}{*}{$\begin{array}{l}\text { Literature } \\
\text { review }\end{array}$} & \multirow[t]{3}{*}{$\begin{array}{l}\text { Indications and evaluation of risk } \\
\text { in } 3 \mathrm{M} \text { extraction. }\end{array}$} & \multirow{3}{*}{$\begin{array}{l}\text { Considerations in deciding treatment: } \\
* \text { Inform the patient of the consequences of } \\
\text { treatment versus no treatment. } \\
* \text { Consider the problems referred to HRQoL, } \\
\text { the clinical problems and economical cost. }\end{array}$} & $\begin{array}{l}{ }^{*} \text { The extraction of 3Ms is considered when } \\
\text { there is clinical and radiographic evidence of } \\
\text { acute or chronic periodontitis, caries, } \\
\text { pericoronitis and deleterious effects upon 2Ms. }\end{array}$ \\
\hline & & & & $\begin{array}{l}\text { * Those } 3 \text { Ms that interfere with orthognathic } \\
\text { surgery or orthodontic treatment should be } \\
\text { removed. }\end{array}$ \\
\hline & & & & $\begin{array}{l}\text { * Advanced age, an increased mandibular } \\
\text { fracture risk, deficient surgical access, } \\
\text { systemic disease and an increased risk of intra- } \\
\text { or postoperative complications may be } \\
\text { contraindications for the removal of } 3 \mathrm{Ms} \text {. }\end{array}$ \\
\hline $\begin{array}{l}\text { Bagheri et al. } \\
2007 \text { (18) }\end{array}$ & $\begin{array}{c}\text { Literature } \\
\text { review }\end{array}$ & $\begin{array}{l}\text { Indications and contraindications } \\
\text { of the prophylactic removal of } \\
\text { impacted } 3 \mathrm{Ms} \text {. Do the cumulative } \\
\text { risks and costs of } 3 \mathrm{M} \text { extraction } \\
\text { exceed the lifelong benefits? }\end{array}$ & Considerations in deciding 3M extraction: & $\begin{array}{l}\text { * The relationship between asymptomatic } 3 \mathrm{Ms} \\
\text { and multiple health risks warrant their removal } \\
\text { in early adulthood. }\end{array}$ \\
\hline
\end{tabular}


Table 1 cont.: Descriptive summary of the studies included in the review.

\begin{tabular}{|c|c|c|c|c|}
\hline & & & * Presence of ongoing symptoms or disease & $\begin{array}{l}\text { * The surgical risk and the complications are } \\
\text { justified when } 3 \mathrm{Ms} \text { are associated to disease } \\
\text { processes (e.g., caries, resorption, pathological } \\
\text { conditions related to cysts and tumors, } \\
\text { periapical abscesses, odontogenic infections, } \\
\text { etc.). }\end{array}$ \\
\hline & & & * Anticipation of future complications & \\
\hline & & & * Morbidity associated to $3 \mathrm{M}$ retention & \\
\hline & & & * Possible risks of extraction at an older age & \\
\hline $\begin{array}{l}\text { Dodson et al. } \\
2007 \text { (23) }\end{array}$ & $\begin{array}{c}\text { Literature } \\
\text { review }\end{array}$ & $\begin{array}{l}\text { Determine the risk of periodontal } \\
\text { defects of } 2 \mathrm{M} \text { after } 3 \mathrm{M} \text { removal. } \\
\text { Specific objective: Among } \\
\text { patients subjected to lower } 3 \mathrm{M} \\
\text { extraction, what is the risk of } \\
\text { periodontal defects distal to } 2 \mathrm{M} \text { ? }\end{array}$ & $\begin{array}{l}\text { * PD or CAL (in } 2 \text { cohort studies and } 5 \mathrm{RCTs} \text { ): } \\
\text { clinically insignificant changes at end of } \\
\text { follow-up }(<2 \mathrm{~mm}) \text {. } \\
\text { * To determine therapeutic efficacy in } \\
\text { extraction of } 3 \mathrm{M} \text { to improve periodontal } \\
\text { condition of } 2 \mathrm{M} \text { (in } 8 \mathrm{RCTs}) \text { : } \\
\text { - Between } 52-100 \% \text { either showed no changes } \\
\text { or improved the disease condition at the site } \\
\text { where } 3 \mathrm{M} \text { was located. }\end{array}$ & $\begin{array}{l}\text { * In the case of pre-existing periodontal } \\
\text { disease, it is suggested that periodontal health } \\
\text { distal to } 2 \mathrm{M} \text { should improve after } 3 \mathrm{M} \text { removal. } \\
* \text { The periodontal health of } 2 \mathrm{M} \text { generally } \\
\text { remains unaltered or improves after } 3 \mathrm{M} \\
\text { removal. }\end{array}$ \\
\hline $\begin{array}{l}\text { Chuang et al. } \\
2008 \text { (16) }\end{array}$ & $\begin{array}{l}\text { Prospective } \\
\text { cohort study }\end{array}$ & $\begin{array}{l}\text { Estimate the frequency of } \\
\text { inflammatory complications } \\
\text { (surgical bed infection and } \\
\text { alveolar osteitis) after } 3 \mathrm{M} \\
\text { extraction and identify the risk } \\
\text { factors for such complications. }\end{array}$ & $\begin{array}{c}\text { N: } 4004 \text { (8748 3Ms) Age: mean } 39.8 \pm 13.6 \\
\text { Variables analyzed in relation to } \\
\text { postoperative inflammation: } \\
\text { - Impaction level, periodontal disease related to } \\
\text { 3Ms, pre-existing infection around } 3 \mathrm{Ms}, \\
\text { disease of } 3 \mathrm{M} \text { (osteitis). }\end{array}$ & $\begin{array}{l}* \text { Impaction level, pre-existing infection and } \\
\text { disease were associated to an increased risk of } \\
\text { postoperative inflammatory complications after } \\
\text { 3M extraction. }\end{array}$ \\
\hline $\begin{array}{l}\text { Kandasamy et } \\
\text { al. } 2009(20)\end{array}$ & $\begin{array}{l}\text { Literature } \\
\text { review }\end{array}$ & Indications of $3 \mathrm{M}$ extraction. & $\begin{array}{l}\text { * Gender, oral contraceptive use, surgeon } \\
\text { experience, presence of disease and degree of } \\
\text { impaction are key parameters in molar } \\
\text { extraction. }\end{array}$ & $\begin{array}{l}* \text { There are clear indications for the removal of } \\
\text { 3Ms associated to disease processes. } \\
* \text { Monitoring is advised in the case of } \\
\text { asymptomatic } 3 \mathrm{Ms} \text {. Surgery should only be } \\
\text { decided following due evaluation of the risks } \\
\text { and benefits for the patient. }\end{array}$ \\
\hline $\begin{array}{l}\text { Krishnan et } \\
\text { al. } 2009(26)\end{array}$ & $\begin{array}{l}\text { Retrospective } \\
\text { study }\end{array}$ & $\begin{array}{l}\text { Indications of 3M extraction in a } \\
\text { dental school in Libya. }\end{array}$ & $\begin{array}{l}\text { N: } 439 \text { M: } 183 / \mathbf{F}: 256 \text { Age: } 15-24 \text { years } \\
\text { (61\%) } \\
\text { Indications for 3M extraction: } \\
\text { - Recurrent pericoronitis (54\%) } \\
\text { - Pulpitis/caries of 3M / } 2 \mathrm{M}(31 \%) \\
\text { - Orthodontics (2\%) } \\
\text { - Cysts/tumors (5\%) } \\
\text { * The most common symptoms were pain and } \\
\text { sensitivity (tenderness). } \\
\text { * The relative absence of prophylactic removal } \\
\text { as an indication could be due to socioeconomic } \\
\text { and logistic factors. }\end{array}$ & $\begin{array}{c}\text { * Knowledge of the indications for the } \\
\text { extraction of a lower } 3 \mathrm{M} \text { will help the } \\
\text { management of these patients. } \\
\text { * Patients generally do not like the idea of } \\
\text { prophylactic removal of } 3 \mathrm{Ms} \text {. } \\
\text { * The removal only of symptomatic lower } 3 \mathrm{Ms} \\
\text { appears to be the most logical option, in view } \\
\text { of the economic and human resource } \\
\text { limitations of the developing countries. }\end{array}$ \\
\hline $\begin{array}{l}\text { Bienstock et } \\
\text { al. } 2011 \text { (14) }\end{array}$ & $\begin{array}{l}\text { Prospective } \\
\text { cohort study }\end{array}$ & $\begin{array}{l}\text { Identify the factors associated to } \\
\text { the duration of postoperative } \\
\text { disability after } 3 \mathrm{M} \text { extraction. } \\
\text { Specific objectives. Identify } \\
\text { factors associated to late } \\
\text { recovery. }\end{array}$ & $\begin{array}{c}\text { N: } 4004,87483 \mathrm{M} \text { removed } \\
\text { Mean duration of postoperative disability: } \\
1.4 \pm 1.8 \text { days (range } 0-26 \text {, median } 1 \text { day). } \\
\text { Earlier return to daily life activities }(\mathrm{p} \\
<0.05 \text { ) was associated to erupting } 3 \mathrm{Ms}, \\
\text { periodontal disease or other preoperative } \\
\text { disease, and chlorhexidine use. }\end{array}$ & $\begin{array}{l}\text { *3M removal is associated with a delay in } \\
\text { return to normal daily life activities of at least } \\
2 \text { days on average. } \\
* \text { A series of factors are significantly } \\
\text { associated with delays in returning to normal } \\
\text { activities (e.g., age, gender and anatomical } \\
\text { position of the } 3 \mathrm{Ms} \text { ). } \\
\text { * One factor - chlorhexidine use - was } \\
\text { associated to briefer disability, possibly } \\
\text { because it reduces the risk of alveolar osteitis. }\end{array}$ \\
\hline \multirow[t]{3}{*}{$\begin{array}{l}\text { Kandasamy et } \\
\text { al. } 2011 \text { (17) }\end{array}$} & \multirow[t]{3}{*}{$\begin{array}{l}\text { Literature } \\
\text { review }\end{array}$} & \multirow[t]{3}{*}{$\begin{array}{l}\text { Individually analyze the } 3 \text { key } \\
\text { criteria for the extraction of } \\
\text { asymptomatic } 3 \mathrm{Ms} \text { : periodontal } \\
\text { disease, age and informed } \\
\text { consent. }\end{array}$} & $\begin{array}{l}\text { * Periodontal disease: carefully evaluate the } \\
\text { recommendation of the AAOMS on the } \\
\text { indications of the early removal of } \\
\text { asymptomatic } 3 \mathrm{Ms} \text {, based on the assumption } \\
\text { that the latter will probably give rise to } \\
\text { periodontal disease in future and could } \\
\text { contribute to systemic disease. }\end{array}$ & $\begin{array}{c}* \text { There are clear indications for the removal of } \\
\text { 3Ms associated to symptoms and disease, as } \\
\text { well as protocols for the removal of } \\
\text { asymptomatic } 3 \mathrm{Ms} \text {. }\end{array}$ \\
\hline & & & $\begin{array}{c}\text { *Age: deciding early } 3 \mathrm{M} \text { removal based } \\
\text { simply on the notion that future extraction will } \\
\text { involve more complications and morbidity is } \\
\text { unfounded. }\end{array}$ & $\begin{array}{c}\text { * The systematic removal of asymptomatic } \\
\text { 3Ms is becoming a practice of the past, in } \\
\text { contrast to the currently viewed primary } \\
\text { obligation to "not cause harm". There are } \\
\text { increasingly fewer excuses for such practice, } \\
\text { which is no longer justified in } \\
\text { contemporaneous dental and medical practice. }\end{array}$ \\
\hline & & & $\begin{array}{l}\text { *Informed consent: inform the patients not } \\
\text { only of the risks of disease if } 3 \mathrm{Ms} \text { are not } \\
\text { removed, but also of the complications } \\
\text { resulting from such extraction. }\end{array}$ & \\
\hline $\begin{array}{l}\text { Marciani } \text { et } \\
\text { al. } 2012 \text { (19) }\end{array}$ & $\begin{array}{l}\text { Literature } \\
\text { review }\end{array}$ & $\begin{array}{l}\text { Estimate the proportion of } \\
\text { patients with asymptomatic } 3 \mathrm{Ms} \\
\text { and evidence of disease at the } \\
\text { start of the study, and assess the } \\
\text { risk health posed by impacted } 3 \mathrm{M} \\
\text { over the long term. }\end{array}$ & $\begin{array}{l}\text { N: } 329 \\
\text { PD in patients with asymptomatic 3Ms: } \\
\mathrm{PD}=5 \mathrm{~mm}: 82(25 \%) \text { at } 3 \mathrm{M} \text { and } 2 \mathrm{M} \text { level } \\
\text { CAL associated to PD: } \\
\text { PD }<5 \mathrm{~mm} \text { was associated to } \mathrm{CAL}=1 \mathrm{~mm} \\
\mathrm{PD}>5 \mathrm{~mm} \text { was associated to } \mathrm{CAL}=2 \mathrm{~mm} \text { in } 80 \\
\text { of } 82 \text { subjects } \\
\text { increase in PD and loss of CAL, together with } \\
\text { periodontal pathogens, were consistent with the } \\
\text { clinical and microbial changes associated with the } \\
\text { start of periodontitis, manifesting first in the } \\
\text { region of } 3 \mathrm{M} \text { in young patients. }\end{array}$ & $\begin{array}{l}* \text { The data suggest that the absence of } \\
\text { symptoms associated to impacted } 3 \mathrm{Ms} \text { is not } \\
\text { synonymous of the absence of disease. } \\
\text { * Those patients that want to retain their } 3 \mathrm{Ms} \\
\text { should undergo periodic clinical and } \\
\text { radiographic controls to detect possible disease } \\
\text { before it causes symptoms. }\end{array}$ \\
\hline
\end{tabular}


Table 1 cont.-1: Descriptive summary of the studies included in the review.

\begin{tabular}{|c|c|c|c|c|}
\hline $\begin{array}{l}\text { Bradshaw et } \\
\text { al. } 2012(24)\end{array}$ & $\begin{array}{l}\text { Prospective, } \\
\text { exploratory } \\
\text { clinical study }\end{array}$ & $\begin{array}{l}\text { Evaluate the effect of } 3 \mathrm{M} \\
\text { extraction upon QoL in patients } \\
\text { with symptoms of pericoronitis. }\end{array}$ & $\begin{array}{c}\text { N: } 60 \text { Age: } 21.9 \text { years } \\
\text { Median postoperative follow-up: } 7.7 \text { months. } \\
\text { Patients reported: } \\
\text { Intense pain decreased after surgery ( } 32 \% \text { to } \\
3 \%) \text {. } \\
\text { A total of } 15 \% \text { experienced pain intensity as } \\
\text { "none", "weak" or "very weak", after } \\
\text { extraction. } \\
\text { A total of } 22 \% \text { and } 18 \% \text { reported "quite a lot" } \\
\text { or "a lot" of eating and chewing difficulties } \\
\text { during the follow-up period. }\end{array}$ & $\begin{array}{l}\text { * Removal of 3M had a positive impact upon } \\
\text { the QoL outcomes in patients with mild } \\
\text { pericoronitis symptoms. }\end{array}$ \\
\hline $\begin{array}{l}\text { Dicus- } \\
\text { Brookes et al. } \\
2013 \text { (3) }\end{array}$ & $\begin{array}{l}\text { Prospective, } \\
\text { longitudinal } \\
\text { clinical study }\end{array}$ & $\begin{array}{c}\text { Evaluate the impact of } 3 \mathrm{M} \\
\text { extraction upon the periodontal } \\
\text { condition of adjacent } 2 \mathrm{M} \text { and } \\
\text { more anterior teeth, in patients } \\
\text { with mild pericoronitis } \\
\text { symptoms. }\end{array}$ & $\begin{array}{c}\text { N: } 69 \mathrm{M}: 45 \% \text {. Caucasians } 57 \% \\
\text { Age: } 21.8 \text { years }(20.2-25.2 \text { years }) \\
\text { Periodontal condition of } 2 \mathrm{M} \text { after } 3 \mathrm{M} \\
\text { extraction: } \\
\text { Initial condition: } \mathrm{PD}>4 \mathrm{~mm} \text { distal to } 2 \mathrm{M} \text { : in } \\
88 \% \text { of the cases. } \\
\text { After surgery: } \mathrm{PD}>4 \mathrm{~mm} \text { distal to } 2 \mathrm{M} \text { : in } \\
46 \% \text { of the cases; } \mathrm{p}<0.01 .\end{array}$ & $\begin{array}{l}* \text { The extraction of } 3 \mathrm{Ms} \text { in patients with mild } \\
\text { symptoms of pericoronitis improved the } \\
\text { periodontal condition of D2M and the more } \\
\text { anterior teeth in the mouth. }\end{array}$ \\
\hline $\begin{array}{l}\text { Steed et al. } \\
2014(6)\end{array}$ & $\begin{array}{c}\text { Literature } \\
\text { review }\end{array}$ & Indications for $3 \mathrm{M}$ extraction. & $\begin{array}{c}\text { Patient symptoms described as: } \\
\text { Present and attributable to } 3 \mathrm{M} \\
\text { Absent } \\
\text { Clinical or radiographic evidence of disease: } \\
\text { Present / Absent }\end{array}$ & $\begin{array}{c}* \text { An asymptomatic } 3 \mathrm{M} \text { does not necessarily } \\
\text { imply the absence of disease. } \\
\text { * The current evidence is not enough to discard } \\
\text { or support prophylactic removal versus } \\
\text { monitoring of asymptomatic } 3 \mathrm{Ms} \text { without } \\
\text { associated disease. } \\
* \text { The evidence warranting extraction versus } \\
\text { monitoring of asymptomatic } 3 \mathrm{Ms} \text { without } \\
\text { associated disease is insufficient. }\end{array}$ \\
\hline $\begin{array}{l}\text { Tang et al. } \\
2014 \text { (22) }\end{array}$ & $\begin{array}{l}\text { Prospective } \\
\text { clinical study }\end{array}$ & $\begin{array}{l}\text { Evaluate how the QoL measures } \\
\text { affect the decision to remove } 3 \mathrm{Ms} \\
\text { in patients with mild pericoronitis } \\
\text { symptoms. }\end{array}$ & $\begin{array}{c}\text { N: } 113 \text { Mean age: } 23.2 \pm 3.8 \text { years } \\
\text { Extraction group: } 79 \text { patients subjected to } \\
\text { removal of } 3 \mathrm{Ms} \\
\text { Non-extraction group: } 34 \text { patients }\end{array}$ & $\begin{array}{l}\text { * The presence of mild pericoronitis and oral } \\
\text { functional and lifestyle problems - factors } \\
\text { which dental professionals do not usually } \\
\text { consider - was significantly associated to the } \\
\text { patient decision to seek early } 3 \mathrm{M} \text { removal. }\end{array}$ \\
\hline
\end{tabular}

\section{References}

1. Qu HL, Tian BM, Li K, Zhou LN, Li ZB, Chen FM. Effect of asymptomatic visible third molars on periodontal health of adjacent second molars: A cross-sectional study. J Oral Maxillofac Surg. 2017;75:2048-57.

2. Li ZB, Qu HL, Zhou LN, Tian BM, Chen FM. Influence of non-impacted third molars on pathologies of adjacent second molars: A retrospective study. J Periodontol. 2017;88:450-6.

3. Dicus-Brookes C, Partrick M, Blakey GH, Faulk-Eggleston J, Offenbacher S, Phillips C, et al. Removal of symptomatic third molars may improve periodontal status of remaining dentition. J Oral Maxi1lofac Surg. 2013;71:1639-46.

4. Sackett DL, Rosenberg WM, Gray JA, Haynes RB, Richardson WS. Evidence based medicine: What it is and what it isn't. Br Med J. 1996;312:71-2.

5. Mettes DT, Nienhuijs MM, Van der Sanden WJ, Verdonschot EH, Plasschaert A. Interventions for treating asymptomatic impacted wisdom teeth in adolescents and adults. Cochrane Database Syst Rev. 2005; 18:CD003879.

6. Steed MB. The indications for third-molar extractions. J Am Dent Assoc. 2014;145:570-3.

7. Syed KB, et al. Prevalence of distal caries in mandibular second molar due to impacted third molar. J Clin Diagnostic Res. 2017;11:28-30. 8. Venta I, Vehkalahti MM, Huumonen S, Suominen AL. Signs of disease occur in the majority of third molars in an adult population. Int $\mathrm{J}$ Oral Maxillofac Surg. 2017;46:1635-40.

9. Venta I. How often do asymptomatic, disease-free third molars need to be removed?. J Oral Maxillofac Surg. 2012;70:41-7.

10. Matzen LH, Villefrance JS, Nørholt SE, Bak J, Wenzel A. Cone beam CT and treatment decision of mandibular third molars: removal vs. coronectomy - a 3-year audit. Dentomaxillofac Radiol. 2019 Nov 28:20190250.

11. Wang D, He X, Wang Y, Li Z, Zhu Y, Sun C, et al. External root resorption of the second molar associated with mesially and horizontally impacted mandibular third molar: Evidence from cone beam computed tomography. Clin Oral Investig. 2017;21:1335-42.

12. Moher D, Liberati A, Tetzlaff J, Altman DG. Preferred reporting items for systematic reviews and meta-analyses: The PRISMA statement. J Clin Epidemiol. 2009;62:1006-12.
13. Stone PW. Popping the (PICO) question in research and evidence-based practice. Appl Nurs Res. 2002;15:197-8.

14. Bienstock DA, Dodson TB, Perrott DH, Chuang SK. Prognostic factors affecting the duration of disability after third molar removal. J Oral Maxillofac Surg. 2011;69:1272-7.

15. Blakey GH, Gelesko S, Marciani RD, Haug RH, Offenbacher S, Phillips C, et al. Third molars and periodontal pathology in American adolescents and young adults: a prevalence study. J Oral Maxillofac Surg. 2010 Feb;68(2):325-9.

16. Chuang SK, Perrott DH, Susarla SM, Dodson TB. Risk factors for inflammatory complications following third molar surgery in adults. J Oral Maxillofac Surg. 2008;66:2213-8.

17. Kandasamy S. Evaluation and management of asymptomatic third molars: Watchful monitoring is a low-risk alternative to extraction. Am J Orthod Dentofac Orthop. 2011;140:11-7.

18. Bagheri SC, Meyer RA. When to refer a patient with a nerve injury to a specialist. J Am Dent Assoc. 2014;145:859-61.

19. Marciani RD. Is there pathology associated with asymptomatic third molars? J Oral Maxillofac Surg. 2012;70:15-9.

20. Kandasamy S, Rinchuse D, Rinchuse D. The wisdom behind third molar extractions. Aust Dent J. 2009;54:284-92.

21. Gutierrez-Perez JL. Third molar infections. Med Oral Patol Oral Cir Bucal. 2004;9:122-5.

22. Tang DT, Phillips C, Proffit WR, Koroluk LD, White RP. Effect of quality of life measures on the decision to remove third molars in subjects with mild pericoronitis symptoms. J Oral Maxillofac Surg. 2014;72:1235-43.

23. Dodson TB, Richardson DT. Risk of periodontal defects after third molar surgery: An exercise in evidence-based clinical decision-making. Oral Maxillofac Surg Clin North Am. 2007;19:93-8.

24. Bradshaw S, Faulk J, Blakey GH, Phillips C, Phero JA, White RP. Quality of life outcomes after third molar removal in subjects with minor symptoms of pericoronitis. J Oral Maxillofac Surg. 2012;70:2494-500. 25. Colorado-Bonnin M, Valmaseda-Castellón E, Berini-Aytés L, Gay-Escoda C. Quality of life following lower third molar removal. Int J Oral Maxillofac Surg. 2006;35:343-7.

26. Krishnan B, Sheikh MH, Rafa EG, Orafi H. Indications for removal of impacted mandibular third molars: a single institutional experience in Libya. J Maxillofac Oral Surg. 2009;8:246-8. 
27. Adeyemo WL. Do pathologies associated with impacted lower third molars justify prophylactic removal? A critical review of the literature. Oral Surg Oral Med Oral Pathol Oral Radiol Endod. 2006;102:448-52. 28. Marciani RD. Third molar removal: An overview of indications, imaging, evaluation, and assessment of risk. Oral Maxillofac Surg Clin North Am. 2007;19:1-13.

29. Richardson DT, Dodson TB. Risk of periodontal defects after third molar surgery: An exercise in evidence-based clinical decision-making. Oral Surg Oral Med Oral Pathol Oral Radiol Endod. 2005;100:133-7.

30. Phillips C, White RP Jr, Shugars DA, Zhou X. Risk factors associated with prolonged recovery and delayed healing after third molar surgery. J Oral Maxillofac Surg. 2003;61:1436-48.

\section{Acknowledgments}

This study was carried out by the "Dental and Maxillofacial Diseases and Therapeutics" research group of the IDIBELL Institute, and forms part of the Clinical Practice Guide "Diagnosis and indications of third molar extraction" auspiced by the Spanish society of Oral Surgery (Sociedad Española de Cirugía Bucal [SECIB]).

\section{Conflicts of interest}

The authors declare that they have no conflicts of interest in relation to this study. 